„Analecta Cracoviensia” 51 (2019), s. 85-98

DOI: http://dx.doi.org/10.15633/acr.3634

Monika Kaczor

ORCID: 0000-0002-7289-933X

Uniwersytet Zielonogórski

\title{
Nieczystość w dyskusjach publicznych
}

Tam, gdzie rządzą moje żądze, tam, niestety, ja nie rządzę.

(J. I. Sztaudynger)

Analizując etykę słowa ${ }^{1} \mathrm{w}$ dyskusjach, które toczą się $\mathrm{w}$ polskiej przestrzeni publicznej, można z łatwością zauważyć, że w specyficzny sposób traktuje się język. Za pomocą słów dyskutujący nie tyle odnoszą się do rzeczywistości po to, by ją adekwatnie nazwać, opisać, lepiej zrozumieć, a następnie wyrobić sobie o niej krytyczny sąd, ile raczej po to, by za każdym razem na nowo stwarzać świat. Język dyskusji publicznych zasadniczo służy do wywierania wpływu na rzeczywistość z wielką furią, nie zaś do jej opisywania. Nie chodzi o słowa adekwatne - chodzi o słowa sprawcze, które tworzą mowę napędzaną i zniekształcaną przez afekty.

Nieczystość, która od wieków jest kojarzona z niemoralnością, seksualizuje obszary życia społecznopolitycznego, które są w społeczeństwie mozolnie deseksualizowane przez purystów językowych.

\footnotetext{
1 Por. M. Kaczor, Czynności mowy, które buduja złe relacje międzyludzkie (na podstawie współczesnych sporów publicznych), w: Kontakty językowe w komunikowaniu, red. M. Steciąg, M. Adamczyk, M. Bieszczanik, Zielona Góra 2016, s. 339-352 (Zielonogórskie Seminaria Językoznawcze 2015). Por. także: J. Puzynina, U podstaw etyki mowy, „Ethos” 2-3 (1988), s. 129-133.
} 
Dyskusje publiczne pokazują, że nieczystość nie jest grzechem tylko ciała, lecz także języka ${ }^{2}$. Nie jest to zjawisko stosunkowo częste, ale na tyle znaczące, że koncentruje myślenie odbiorcy zmierzające do wydobycia i wyjaśnienia sensu (swoistości), a w szczególności określenia znaczeń ukrytych, które są możliwe do opisania, gdy ulokuje się określone sformułowanie w odpowiednim (szerszym) kontekście społecznopolitycznym. Sfera powiązań i odniesień międzytekstowych, w których pojawiają się sformułowania odnoszące się do sfery nieczystości, ujawnia znaczenie i wartość określonego fragmentu rzeczywistości pozajęzykowej.

Język dyskusji publicznych ${ }^{3}$ dowodzi, że nieczystość dotyczy relacji międzyludzkich, a w szczególności naszego stosunku do człowieka, a stosunek ten ma odzwierciedlenie w słowach, w procesach poznawczych polegających na wyrażaniu opinii, komentowaniu, skojarzeniach, wnioskowaniu. Kontakty interpersonalne wyrażające się mową to obszar stosunku do drugiego człowieka. Istnieje zależność między agresją słowną i wulgaryzacją języka a przemocą fizyczną i obscenicznością zachowań, co dowodzi jakości języka publicznego ${ }^{4}$.

2 O grzechach głównych w dyskusjach publicznych por. następujące teksty: M. Kaczor, Jak uczestnicy dyskusji publicznych wypowiadają się o chciwości? Próba rekonstrukcji znaczenia, w: Media Biznes - Kultura, red. B. Czechowska-Derkacz, D. Chomik, J. Wojsław, t. 2, Gdańsk 2018, s. 111-129; M. Kaczor, „Lenistwo przerasta nasze siły”. Etyczno-moralny wymiar lenistwa (na przykładzie dyskusji publicznych), „Komunikacja i Konteksty” 1 (2018), s. 49-61; M. Kaczor, Zazdrość jako problem etyczny (na przykładzie dyskusji publicznych), w: Etyka w komunikacji, red. G. Habrajska, Łódź 2018, s. 129-144 (Teorie i Praktyki Komunikacyjne).

„Nie pójdę też droga zżerającej zazdrości, bo ona z Mądrością nie ma nic wspólnego” (Mdr 6, 23). Zazdrość jako problem etyczny (na przykładzie dyskusji publicznych). Ujęcie językoznawcze - w druku; M. Kaczor, Struktura znaczenia leksemu pycha (na podstawie współczesnych debat publicznych). Szkic językowy, „Prace Naukowe Akademii im. Jana Długosza w Częstochowie. Filologia Polska. Językoznawstwo” 12 (2016), s. 107-120.

3 Por. M. Kaczor, Krótko, ostro, do słuchu. Język współczesnych sporów publicznych (na przykładzie dyskusji o uchodźcach i migrantach w „Tygodniku Powszechnym”), w: Aksjologiczne aspekty komunikacji. Materiały z Forum Etyki Słowa, red. I. Benenowska, E. Laskowska, B. Morzyńska-Wrzosek, Bydgoszcz 2019, s. 81-98.

4 W latach sześćdziesiątych xx wieku wybitny polski językoznawca Zenon Klemensiewicz napisał artykuł apelujący o higienę w językowych kontaktach. Por. Z. Klemensiewicz, Higiena językowego obcowania, „Język Polski” 45 (1965) z. 1, s. 1-8. Odnosząc ten tekst do analizowanego materiału, można stwierdzić, że ładu społecznego i „higienicznych stosunków międzyludzkich”, dobrej atmosfery nie tworzy się językiem, który drażni brakiem przyzwoitości, nadużyciami i drwi z kulturalnych wymogów obyczajowych. 
Obecność w języku sformułowań odnoszących się do nieczystości pokazuje, że do społecznego myślenia wkradły się określenia, które budzą niesmak, zaś smak w języku został zastąpiony poniżaniem jego funkcji zwłaszcza estetycznej.

Nieczystość to temat niemarginalny, plasujący się w obszarze patologii społecznych. W dyskusjach publicznych pojawiają się wyrażenia, w których odbijają się - jak w krzywym zwierciadle - głębokie, często nieuświadamiane trendy społeczne. Są one ważnym źródłem wiedzy o moralności społecznej. Sformułowania, w których widoczne są odwołania do nieczystości, szerzą się w języku z siłą i agresywnością ${ }^{6}$. Wdzieranie się tego elementu w dzisiejszą kulturę myślenia jest często brutalne, zaś takie cnoty jak czystość, wstydliwość, powściągliwość w języku wydają się zupełnie zanikać. Obecność tych ostatnich w języku zawsze skutkuje większą delikatnością, refleksją nad wypowiadanymi treściami, szacunkiem dla odbiorcy.

Celem artykułu jest odpowiedź na pytanie, czym jest nieczystość w języku, jak zostaje ona zwerbalizowana i jak się przejawia. Dlaczego w myśleniu społecznym pewne sprawy kojarzą się z seksualnością? Dlaczego słowo zapożyczone ze sfery estetycznej jest tak istotne dla moralności życia społeczno-politycznego?

Takie określenia, jak: „gwałt polityczny”, „molestowanie polityczne”, „nierząd polityczny”, ,prostytucja polityczna”, „, ,rozpusta polityczna”, „rozwiązłość

5 W analizowanych dyskusjach, w których pojawiały się nawiązania do nieczystości, ważne są również komentarze uczestników dyskusji obudowujące wątek główny dyskusji. Są w nich widoczne interpretacje odwołujące się do nieczystości w kontekście moralności (etyki) społecznej: „Nieczystość wciąga jak bagno. Coraz głębiej. I chyba jak w żadna inna wada domaga się coraz to nowych doznań. Najlepiej odkrywania nowego, dotąd niedoświadczonego. Stąd zjawisko eskalacji potrzeb. Najpierw bagna jest po kostki, potem po kolana, a w końcu po szyję. [...] Nieczystość bywa też zaraźliwa. Nieczysty nieraz brudzi innych. Wskutek jego działań oni też z czasem stają się nieczyści. I swoim brudem też zaczynają obdzielać innych, zwłaszcza niedoświadczonych w życiu politycznym, mniej osobowościowo ustabilizowanych, bardziej skłonnych do szukania nowości. Przecież wszyscy tacy są, nie ma co udawać, że jest inaczej. I zło się rozlewa” („Gość Wiadomości”, 4.06.2017); „Niestety jest ona czymś powszechnym, bo człowiek zwiedziony blichtrem chętniej idzie za błyskotką niż prawdziwą wartością; sięga po to, co bliższe i łatwiejsze, zapominając o tym, co istotne; zwraca uwagę na szczegół, nie dostrzegając, że jest on zaledwie częścią całości” („Warto rozmawiać", 16.03.2017).

6 Por. M. Peisert, Formy i funkcje agresji werbalnej. Próba typologii, Wrocław 2004, passim; Język porozumienia, język agresji, język alienacji, w: J. Puzynina, Słowo-wartość-kultura, Lublin 1997, s. 76-81. 
polityczna"7 mogą niepokoić, ponieważ świadczą o tym, że temat nieczystości nie jest zbyt intymny w życiu publicznym i nie ma trudności w mówieniu o nim. W sporach publicznych przekracza się próg świadomości etycznej, mimo różnego pojmowania wstydu, różnych zahamowań ${ }^{8}$ i tabu ${ }^{9}$. Takie myślenie w języku jest zubożające i degradujące ${ }^{10}$.

Wspomniane określenia ${ }^{11}$ uzasadniają niestosowność czynów oraz zachowań, a także uwydatniają właściwości opisywanego zjawiska w życiu społeczno-politycznym przez wskazanie na podobieństwo do zjawiska ze sfery seksualności. Język i sposób, w jakim myślimy o sferach życia społeczno-politycznego, wydają się być „na sprzedaż” ${ }^{12}$. Wspomniane określenia w odczuciu niektórych użytkowników języka mogą naruszać zakazy obyczajowe utrwalane w języku. Otwierają umysł na różnorodność nieczystych obrazów i sugestii, prowadzących do przesadności, braku umiaru, niewstrzemięźliwości, do niestosownych, niegodziwych działań, przekraczających określoną granicę moralności społecznej.

Sfera spraw, o których „się mówi”, odwołując się do nieczystości, jest stosunkowo rozległa ${ }^{13}$. Użytkownicy języka nie wstydzą się o niej mówić, komentując

7 W cytowanym artykule Klemensiewicz o tego rodzaju sformułowaniach, które nawiązują do drażniących sytuacji z dziedziny przeżyć seksualnych, mówi, że „skazują na cierpienia natury duchowej” (s. 4). I dalej: „mącą spokój duchowy”, „zagrażają równowadze psychicznej społeczeństwa” (s. 6). Są ordynarne, sprośne, plugawe, bezwstydne, prostackie, charakteryzują się prymitywną i sadystyczną lubieżnością. Przekraczają publiczną przyzwoitość. To wyraz chuligaństwa językowego i językowego schamienia, które nie są środkiem społecznie skutecznym. Mają dużą szkodliwość społeczną, ponieważ przyczyniają się do patologicznej zdrożności mowy i obniżają dyscyplinę obyczajową przez dosadną wierność brutalnej rzeczywistości.

8 Por. B. McNair, Seks, demokratyzacja pożądania i media, czyli kultura obnażania, Warszawa 2004, passim.

9 Por. M. Kaczor, Tabu a funkcja estetyczna języka, „Język Polski” 83 (2003) z. 1, s. 46-49.

10 R. Pawłowska, Język rani i obraża, „Język-Szkoła-Religia” 6 (2011), s. 264-268.

${ }^{11}$ Jestem świadoma, że zebrany przeze mnie materiał na potrzeby tego tekstu nie jest liczny, ale może stanowić pretekst do rozważań na temat nieczystości w języku wystąpień publicznych.

${ }^{12}$ Por. J. Bralczyk, Język na sprzedaż, Gdańsk 2008, s. 18.

13 Interpretowanie lub komentowanie rzeczywistości społeczno-politycznej za pomocą sformułowań odnoszących się do sfery nieczystości pojawiło się w sporach publicznych na tematy dotyczące korupcji członków frakcji politycznych („Korupcja wśród polityków przybiera formę rozwiązłości politycznej”, „Warto rozmawiać”, 16.03.2017), reprywatyzacji warszawskich kamienic („Patologie warszawskiej reprywatyzacji, czyli molestowanie polityczne, którego ofiarami są udręczeni do granic możliwości mieszkańcy, a napastnikiem warszawski ratusz”, „Wiadomości”, 18.03.2018), upadku polskich instytucji finansowych („Szafowanie majątkiem bankowym to nie tylko afera, ale rodzaj rozpusty politycznej”, „Fakty po Faktach”, 12.06.2017), próby sprzedaży 
różne fragmenty rzeczywistości społeczno-politycznej. Nie wyczuwają również ryzyka nadużyć ${ }^{14}$.

Z jednej strony próbuje się wpisać sferę płciowości w inne sfery życia (władzy, porząaku społecznego, bezpieczeństwa państwa, finansów publicznych, etosu urzędnika publicznego), pokazując, że są one „nieczyste” i traktowane przedmiotowo. Z drugiej - wymienione wyżej sformułowania zwracają uwagę na to, że wokół sfery płciowości $i^{15}$ skupia się wiele spraw społeczno-politycznych, które do jej istoty nie należą i nie są jej treścią. Element związany z seksualnością nie został w nich zamknięty we właściwych granicach.

Nazywanie pewnych zjawisk społeczno-politycznych za pomocą metafor związanych ze sferą płci może świadczyć o tym, że wstyd w języku przestał być wyrazem troski o ochronę delikatnej rzeczywistości, która z pewnych względów jest dla człowieka ważna. Dowodzić może również tego, że w języku zanikają dobre obyczaje, a nieczystość się ulepsza i przestaje być wstydliwa. W dyskusjach publicznych odwoływanie się do nieczystości jest wyrazem nieskromności w języku, która jest skutkiem tego, że zanika komunikacja międzyludzka (personalna), a upowszechnia się obsceniczne ściągnie uwagi na pewne fragmenty rzeczywistości pozajęzykowej za pomocą ,walczących słów”'16. Bezwstydnie nazywa się określone postawy i zachowania występujące w życiu społeczno-politycznym, obnaża myślenie z nieskromności, co sprzyja

spółek lotniczych („Brano od uwagę sprzedaż spółek lotniczych za granicą. Polska nierządem politycznym stoi”, „Gość Wiadomości”, 4.06.2017), katastrofy lotniczej polskiego samolotu wojskowego pod Smoleńskiem („To, co dokonano w Smoleńsku z przedstawicielami polskiego rządu, to zakrawa na gwałt polityczny”, „Kawa na ławę”, 4.06.2017), transferów politycznych („Niektórzy posłowie mogą sobie w życiorys wpisać coś, co nazwałbym prostytucją polityczną,", „Kropka nad i”, 17.05.2017).

${ }^{14}$ Konteksty, w których pojawia się nawiązanie do „nieczystości” w sporach publicznych, nie dotykają sfery religijnej. Jak się wydaje, tego rodzaju sformułowania wyznaczają nową retorykę grzechu.

${ }^{15}$ Biorąc pod uwagę zakres słownikowy, synonimami „nieczystości” są: sprośność, lubieżność, wyuzdanie, pożądliwość, bezwstydność, rozpasanie, nieprzyzwoitość, nieskromność, zmysłowość, cielesność, deprawacja, żądza, rozpusta, wulgarność, wszeteczeństwo, obsceniczność, orgiastyczność, trywialność, perwersja, niemoralność, gnuśność, nierząd, erotyzm, pornografia, dewiacja, zboczenie, degeneracja, aberracja, ekscytacja. Por. Stownik języka polskiego, red. W. Doroszewski, t. 1-11, Warszawa 1958-1969; Stownik języka polskiego, red. M. Szymczak, t. 1-3, Warszawa 1978-1981; Praktyczny stownik wspótczesnej polszczyzny, red. H. Zgółkowa, t. I-L, Poznań 1994-2005; Stownik wspótczesnego języka polskiego, red. B. Dunaj, t. 1-2, Warszawa 1996; Komputerowy słownik języka polskiego, Warszawa 200o; Uniwersalny stownik jezyka polskiego, red. S. Dubisz, t. 1-6, Warszawa 2003.

${ }^{16}$ Por. J. Butler, Walczące stowa. Mowa nienawiści i polityka performatywu, Poznań 2010, passim. 
zepsuciu obyczajów i umacnianiu mechanizmów negatywnej selekcji. Prowokuje to także złe emocje i skrajne wypowiedzi ${ }^{17}$; niszczy i tak skromny poziom społecznego zaufania. Tego rodzaju sformułowania przedstawiają funkcjonowanie określonych sfer życia politycznego jako źródło zła i politycznego zepsucia sfery publicznej. Można przypuszczać, że jest to niesmaczny element językowej gry wizerunkowej między frakcjami politycznymi. Efektem takiego stanu powinna być mobilizacja sprzeciwu wobec złych praktyk językowych i społecznego znieczulenia ${ }^{18}$.

Można zaryzykować stwierdzenie, że tego rodzaju sformułowania stały się walutą, za którą kupuje się poparcie wyborców i zainteresowanie telewidzów. Przekraczają normy, są pewnego rodzaju zabiegiem retorycznym, wynoszącym nieczystość na nowe poziomy. Pozwalają stawiać pytania o powody nazywania za pomocą takich określeń zjawisk życia publicznego, które nie mogłyby paść bez uprzedniego złamania tabu językowego. Mogą być one pretekstem do redefiniowania moralnych wartości.

Określenia „gwałt polityczny”, „molestowanie polityczne”"19, „nierząd polityczny”, „prostytucja polityczna”, „rozpusta polityczna”, „rozwiązłość polityczna” są ogołocone z jakichkolwiek znaczeń moralnych. Mają u podstaw amoralność (niemoralność). Widoczna jest w nich nabierająca mocy norma zachowania, odwołująca się do natychmiastowego popędu i braku panowania nad sobą, a więc norma, która została pozbawiona jakichkolwiek etyczno-moralnych zasad.

W dyskusjach publicznych pojawiają się sformułowania, które są przykładem buntu wobec czegoś, co uważa się za krępujące więzy, i to bez względu na to, czy są one naturalne, czy kulturowe. Przywołane wcześniej sformułowania wskazują na to, że za pomocą języka wypracowuje się nowy kodeks, który nie miałby norm, ale nakazywałby kierowanie się jedynie tym, co dostępne od razu: „nieregularnością”, popędem.

${ }_{17}$ Por. J. J. Jadacki, Zły język, w: Etyka międzyludzkiej komunikacji, red. J. Puzynina, Warszawa 1993, s. 33-38.

${ }_{18}$ Por. J. Puzynina, O zasadach współdziałania językowego, „Prace Filologiczne” 33 (1986), s. $61-66$.

19 Reakcją dziennikarza prowadzącego program na pojawienie się tego sformułowania były słowa: „Zaczynają się wdzierać do dyskusji kosmate myśli...” („Warto rozmawiać”, 16.03.2017). Z łatwością można w nich dostrzec odwołanie do myśli nieprzyzwoitych, bezwstydnych, zdrożnych, zazwyczaj dotyczących seksu, erotyki. 
W sporach publicznych nieczystością się manipuluje, pozbawia się ją pierwotnego znaczenia, wypacza się jej znaczenie, chcąc pokazać „niewinną bezinteresowność" określonej frakcji politycznej ${ }^{20}$. Jednocześnie używając jej jako broni w walce z przeciwnikiem politycznym, wskazuje się na zrobienie przez niego czegoś niewłaściwego, niemoralnego, co skutkuje tym, że przestaje być godnym szacunku. Przywołane wcześniej określenia mogą świadczyć o tym, że w relacjach społeczno-politycznych brak więzi osobowej, nawiązywania i kultywowania odpowiedzialnych i dojrzałych relacji, których fundamentem jest szacunek dla drugiego (nawet adwersarza politycznego). W ten sposób język nie tylko wyraża upowszechniające się praktyki językowe, ale także charakteryzuje relacje międzyludzkie, zdominowane przez egoizm, których nie da się uwolnić $\mathrm{z}$ pożądania.

Za pomocą sformułowań, które mają związek z nieczystością, opisuje się rzeczywistość z perspektywy ludzi bezgrzesznych, moralnie, ideologicznie i egzystencjalnie czystych. Nieczystość jest dla dyskutujących atrybutem inności i zasługuje na potępienie, jak wszystko, co w sposób niewłaściwy narusza cielesność człowieka. To widoczne jest również w języku - „rozpusta”, „nierząd” czy „rozwiązłość” oznaczają brak hamulców, rozerwanie istniejących aprobowanych społecznie i kulturowo więzi, chaos, pragnienie zawładnięcia drugim, przemoc, relacje patologiczne ${ }^{21}$. Nieczystość jest wyrazem błędnego rozeznania wartości, wprowadza w relacje społeczne dysharmonię, fałsz, udawanie, postawę roszczeniową, manipulację, zawłaszczenie, uprzedmiotowienie. Istotą nieczystości jest używanie drugiego człowieka jako przedmiotu czy środka do celu. Takie strategie językowe w komunikowaniu publicznym muszą budzić dyskomfort psychiczny.

Przywołane wcześniej wyrażenia są metaforycznymi opisami „chorób” w sferze społeczno-politycznej - zwłaszcza „chorób” naruszających obowiązujące konwencje w etycznej komunikacji językowej, mające na celu szokowanie, przekraczanie społecznego tabu, ujawnianie wstydliwego pożądania, niemieszczącego się w powszechnie przyjętych konwenansach ${ }^{22}$.

${ }^{20}$ Por. M. Karwat, O złośliwej dyskredytacji. Manipulowanie wizerunkiem przeciwnika, Warszawa 2006, s. 174-189.

${ }^{21}$ Na pytanie dziennikarza, czy określenie „prostytucja polityczna” nie jest przekroczeniem pewnej granicy przyzwoitości, polityk odpowiedział w następujący sposób: „Nie podobają się mocniejsze sformułowania, a przecież oczywiste jest, że czasem trzeba powiedzieć coś mocniej, aby to dotarło do ludzi” („Kropka nad i”, 17.05.2017).

${ }^{22}$ R. Grzegorczykowa, O działaniach zamierzonych i mimowolnych, w: Words are physicians for an ailing mind, eds. M. Grochowski, D. Weiss, München 1991, s. 195-200 (Sagners Slavistische 
Przytoczone zuchwałe i prowokacyjne sformułowania implikują skojarzenia z czymś więcej niż akt fizyczny, odbiegający od normy, nieprzyzwoity. Potwierdzają one, że o pewnych zjawiskach użytkownicy języka myślą, przywołując określenia właściwe prostackiej i niecnej pornografii, bezwstydnej i bezczelnej rozwiązłości, które są świadectwem degeneracji i deprawacji w języku oraz kulturze myślenia. U źródeł ich znaczenia leży przykre wypaczenie i upokorzenie właściwych relacji międzyludzkich.

Nowe, przenośne znaczenie tych wyrażeń kształtuje się na fundamencie znaczeń dotychczasowych pod presją szczególnych okoliczności użycia. Zamierzona zmiana znaczeń, która zachodzi w obrębie tych wyrażeń, tworzy nowe wyobrażenia oraz wskazuje na ukryte powinowactwa w języku, jak i w rzeczywistości społecznej. Z pewnością nazywanie nimi określonych fragmentów świata realnego może zaskakiwać, zastanawiać, wyrażać nieznane sensy, tworzyć nowe wyobrażenia. W tych sformułowaniach uchwycenie więzi uzasadniających ich dziwne połączenie jest odkrywcze i deformujące zarazem, bo prowadzi do ujawnienia rzeczywistych zależności. Szokować może odkrycie podobieństwa w zjawiskach niepodobnych.

Charakterystycznym sformułowaniem, które pojawiło się jako element oceniający sposób działania określonych frakcji politycznych, jest stwierdzenie „Zachowali się nieczysto” (Warto rozmawiać, TVP, 16.03.2017). Konkretnie, krótko, ale w pełny sposób zostało ujęte to, że nieczystość prowadzi do moralnej, a często i emocjonalnej, przepaści. W tym fragmencie wypowiedzi widać, że nazwy czynności określające grzechy dotyczące sfery seksualnej przenosi się na określenie sposobu prowadzenia życia publicznego. Pokazuje to również, że nieczystość funkcjonuje w życiu społecznym w emocjach i w poczuciu bycia grzesznym. Życie publiczne stało się aspektem „nieczystego doświadczenia", jest więc prymitywne i zwulgaryzowane. Tym samym to, co w życiu publicznym zostaje określone jako nieczyste, jest niepożądane i obrzydliwe. W ocenie dyskutujących te określenia są jasne i wystarczające do (nie)moralnej klasyfikacji czyjeś działalności, czynu, zachowania, postępowania. Można zaryzykować stwierdzenie, że cielesność jest elementem życia społecznego, a życie publiczne zostało sprowadzone do ciała i zseksualizowane ${ }^{23}$. W sprawach tak rozumianej nieczystości w sporach publicznych część dyskutujący

\footnotetext{
Sammlung, 17).

${ }^{23}$ Seksualność, która pojawia się w dyskusjach publicznych, nie funkcjonuje w rozumieniu zdolności do podtrzymywania ważnych dla społeczeństwa więzi, budowania intymnych i bliskich relacji.
} 
odwołuje się do etyki moralności - są oni strażnikami prawa, rzecznikami kodeksów prawa, sędziami powinności. Ten etap dyskusji publicznych został sprowadzony do tego, czego „nie wolno pożądać” ${ }^{24}$.

Nieczystość wiąże się bezpośrednio ze złym postępowaniem. Uwikłanie się w nią skutkuje nie tylko grzechem przeciw ciału, ale jak to pokazują spory publiczne - również obciążeniem ducha i nieuporządkowaniem pragnień. Postawa nieczystości, podobnie jak pycha i chciwość, jest pewną postawą egzystencjalną. Nieczystość w swej głębi nie jest tylko sprawą ludzkiego ciała, ale ludzkiego serca i sama w sobie jest źródłem innych grzechów. Ma wiele wspólnego $\mathrm{z}$ idolatrią, której przedmiotem $\mathrm{w}$ tym zakresie są niewłaściwy stosunek do dóbr materialnych i uprzedmiotowienie relacji międzyosobowych.

Ze zgromadzonego przeze mnie materiału badawczego widać, że w sferze życia publicznego pojawiają się sprawozdania z takich zachowań, jak: wymuszenia, szantaże emocjonalne, zakazana przez prawo przemoc fizyczna, świadome odstępstwa od przyjętych przez daną społeczność norm i wartości, jawna lub ukryta działalność przeciw nim, uzależnienia rodzące się w stosunku do zysków materialnych i do innych ludzi. Uczestnicy dyskusji publicznych odowłują się do obrazów nieczystości, która jest wyrazem nieetycznych (niemoralnych, grzesznych) czynów. W niej jak w zwierciadle odbiją się wartości społecznych przemian.

Przez przyzwolenie na nieczystość próbuje się tworzyć przestrzeń dla usprawiedliwiania nieetycznych czynów. Niektóre z nich szczególnie gorszą opinię publiczną, bo mają miejsce w środowiskach, które powinny świecić przykładem przyzwoitości, będącej synonimem czystości. Te gorszące i niszczące fakty nieczystości to przejawy zachwiania równowagi głębokiej postawy wewnętrznej, sięgającej ludzkiego ducha, a także nieumiejętności podporządkowania rozumowi i woli sfery materialnej i relacji międzyosobowych. Wspomniane wcześniej sformułowania uświadamiają, że jeśli człowiek widzi jedyne i ostateczne źródło swego bezpieczeństwa i spełnienia w relacjach międzyludzkich i osiąganiu dóbr materialnych czy zysków finansowych, musi wejść w jakąś egzystencjalną i duchową formę nieczystości, czy to jawną, czy ukrytą - niekiedy

${ }^{24}$ „W tej naszej dzisiejszej dyskusji nie chodzi o jakiś zestaw zasad, z których mielibyśmy wyciągnąć proste wnioski po to, by zachowywać się moralnie. Chodzi o to, aby być wyczulonym na dobre działania w życiu społecznym, uczyć się odróżniać głębokie autentyczne pragnienia od efemerycznych zachcianek zależnych od okoliczności i nieświadomych przejawów pożądania” („Fakty po Faktach”, 12.06.2017). 
tak dalece ukrytą, że dopiero zupełnie niespodziewany upadek pozwala mu ją odkryć.

W życiu publicznym, zwłaszcza tym nagłośnionym w mediach, nieczystość staje się ogólną demoralizacją. Z językoznawczego punktu widzenia dyskusje publiczne nad sposobami bronienia się przed nieczystością dostarczają cennego, dobrego materiału, który może przybliżyć jej aspekty znaczeniowe - zwłaszcza te powszechnie uświadamiane. Warto przy tym zaznaczyć, że użytkownicy języka nie posługują się leksemem „nieczystość”, a nawet co wyraźnie zaobserwowałam - unikają go. Mówiąc o nieczystości w życiu publicznym, używają jej synonimów ${ }^{25}$.

Przywoływanie nieczystości w dyskusjach publicznych zawiesza niejako pożądane kategorie funkcjonujące w społeczeństwie: etyczne, estetyczne, a nawet egzystencjalne. Świadomość niedoskonałości relacji społeczno-politycznych każe oczyszczać je z brudu, z wszystkiego, co nie pozwala im poprawnie funkcjonować, co może oddalać od drugiego człowieka i narażać stosunki międzyludzkie na zniszczenie. Określenia z komponentem „nieczystość” są wyrazem klęski społecznej i moralnej, skutkiem niszczenia godności osoby ludzkiej, ale i świadectwem gorącego sprzeciwu wobec tej krzywdy. Strony polityczne używające wspomnianych sformułowań widzą w postawie swoich przeciwników dobrowolne i systematyczne oddawanie się złu czy też świadomy wybór zła, nie biorąc pod uwagę złożoności różnych sytuacji społeczno-politycznych.

${ }^{25} \mathrm{~W}$ obserwowanych przeze mnie dyskusjach nad wydarzeniami oburzającymi opinię publiczną, na określenie nieczystości dyskutujący używali takich synonimów, jak: afera, balgierka, bałamuctwo, bandytyzm, bezczelność, bezeceństwo, bezprawie, bezwstydność, blagowanie, brak skrupułów, brak zgodności z prawem, chuligaństwo, chytrość, ciemny interes, cios poniżej pasa, cwaniactwo, cyganienie, cynizm, defraudacja, demoralizacja, diaboliczność, draństwo, dwulicowość, fałsz, fałszowanie, faryzeizm, gałganeria, granda, grzech, haniebność, hipokryzja, hosztaplerstwo, jawny wyzysk, kanciarstwo, karygodność, katowanie, kitowanie, kiwanie, kombinowanie, korupcja, krętactwo, kuglowanie, łajdactwo, łapownictwo, łganie, łotrostwo, machinacje, malwersacje, małoduszność, manipulowanie, mataczenie, moralność Kalego, nabijanie w butelkę, naganność, naruszenie prawa, nieczysta sprawa, niedopuszczalność, nieetyczność, niegodziwość, nielegalność, niemoralność, niepraworządność, nieprzyzwoitość, nierzetelność, nieszlachetność, nikczemność, niskość, ocyganienie, odrwienie, okłamywanie, oszkapianie, oszukaństwo, oszwabianie, perfidia, podchwytliwość, podłość, podstęp, podwójna moralność, pokrętność, przebiegłość, przejście na stronę przeciwnika, przekręt, przekroczenie granic moralnych, przekupność, przeniewierstwo, przestępstwo, przewałka, przewrotność, rabunek, rolowanie, rozbój w biały dzień, skandaliczność, spekulanctwo, sprzedajność, szachrajstwo, szarlataństwo, szatańskość, szelmostwo, szubratswo, szwindel, świniowatość, wykroczenie, wyłudzanie, wyrachowanie, wyrafinowanie, występek, wyzysk, zakłamanie, zwodniczość. Pokazują one, jaki zakres działań niemoralnych obejmuje nieczystość. 
Sądy w nich zawarte opierają się najczęściej na opinii ogółu lub obserwacji pojedynczych faktów, z których wyprowadza się daleko idące uogólnienia, zabarwione dużym ładunkiem emocjonalnym.

Warto byłoby poczynić rozważania nad sformułowaniami „gwałt polityczny”, „molestowanie polityczne”, ,nierząd polityczny”, „prostytucja polityczna”, „rozpusta polityczna”, „rozwiązłość polityczna”"26 na płaszczyźnie filozofii moralności i jej aksjologii oraz tego, jak się pojmuje krytykę społeczną jako społeczną praktykę budowania dobra wspólnego i dbania o nie. Nie bez znaczenia jest również refleksja na tym, jak rozumiemy moralną rzeczywistość i jej tworzenie.

Należy jednak zauważyć, że wspomniane określenia nie stoją na jednym poziomie $\mathrm{z}$ nieczystością $\mathrm{w}$ znaczeniu cielesności. Utrwalają one zjawisko omawianej wady w jej ludzkich znaczeniach, zachowaniach, postępowaniach i wyborach. Choć widać w nich wyraźną ocenę moralną, to nie mamy tu do czynienia z jakimś obrazem seksualnym, nieprzyzwoitością jako celem samym w sobie. Można zaryzykować stwierdzenie, że budują one językowy obraz moralności społecznej z wyszukaną ekstrawagancją.

Przytoczone sformułowania dowodzą, że w dyskusjach publicznych pojawia się nieczysta, szkaradna, wyuzdana mowa (brudna rozmowa), przez którą wyraża się na zewnątrz to, co się myśli. Dlatego język uwikłany w nieczystość nie służy przedstawianiu świata, tworzeniu komunikacyjnej więzi czy podmiotowej ekspresji. Taki język bierze w posiadanie społeczeństwo, a w szczególności jego myślenie i chwilowe panowanie nad rzeczywistością.

Nieczystość w języku odsłania świat społeczny porządkowany nie przez staranne wybory aksjologiczne, lecz przez fobie. Komunikacja społeczna nie toczy się na poziomie racjonalnym, lecz na poziomie języka wyrażającego w obsceniczny sposób frustracje różnych stron sporów publicznych. Granice tego, co szokujące, zakazane i ukryte w języku, przesuwają się w niepokojącym tempie. Rozerotyzowany język dyskusji publicznych można odbierać jako skandal, prowokację albo przyczynek do socjologicznej analizy. Udawanie, że taki

${ }^{26} \mathrm{Z}$ moich obserwacji wynika, że tego rodzaju sformułowania w dyskusjach publicznych pojawiają się incydentalnie, w sytuacjach wzburzonych dyskusji nad ładem moralnym w państwie, w sytuacjach wzburzających opinię publiczną wydarzeń, po ujawnieniu czynów sprzecznych z zasadami moralnymi. Towarzyszą one rozważaniom nad zasadami albo przejawami i skutkami łamania określonych zasad moralnych oraz ocenami tych zjawisk.

Zwraca uwagę zjawisko synonimiczności i bliskoznaczności w nazywaniu różnych przejawów nieczystości jako niemoralności społecznej. 
język nie istnieje, z roku na rok jest coraz trudniejsze. Granicą są wrażliwość użytkowników języka (odbiorców) i dobre obyczaje w języku.

\section{ABSTRAKT}

Celem referatu jest omówienie nieczystości w dyskusjach publicznych, która wykracza poza dobre obyczaje językowe. Jest to forma nadużycia językowego, obniżająca publiczną przyzwoitość.

W sporach publicznych nie myśli się o niej w znaczeniu religijnym, ale przede wszystkim w kontekście moralności społecznej, a w szczególności zasad moralnych.

O „nieczystości” mówi się tam, gdzie dostrzega się słabość moralną człowieka, jego stan moralnie patologiczny, dno, upadek, brak umiejętności konsekwentnego kierowania się zasadami moralnymi i podporządkowania im swojego działania w sferze społecznej. Przez „nieczystość” użytkownicy języka wskazują na niemożliwość zaakceptowania krzywdy człowieka, niesprawiedliwego prawa, bezczynności wobec zła.

\section{SEOWA KLUCZOWE}

etyka słowa, higiena werbalna, moralność społeczna, nieczystość, tabu

\section{ABstract}

\section{Impurity in Public Discussions}

The purpose of the paper is to discuss impurity in public discussions that goes beyond good language practices. It is a form of linguistic abuse that reduces public decency.

In public disputes, it is not thought of in a religious sense, but primarily in the context of social morality, and in particular moral principles.

The "uncleanness" is spoken of where one sees the moral weakness of man, his morally pathological condition, bottom, fall, lack of the ability to consistently follow moral principles and subordinate them to their actions in the social sphere. Through "uncleanness," language users point to the inability to accept human harm, unfair law, and inaction against evil.

\section{KEYWORDS}

word ethics, verbal hygiene, social morality, impurity, taboo 


\section{BIBLIOGRAFIA}

Bralczyk J., Język na sprzedaż, Gdańsk 2008.

Butler J., Walczace słowa. Mowa nienawiści i polityka performatywu, Poznań 2010.

Grzegorczykowa R., O działaniach zamierzonych i mimowolnych, w: Words are physicians for an ailing mind, eds. M. Grochowski, D. Weiss, München 1991, s. 195-200 (Sagners Slavistische Sammlung, 17).

Jadacki J. J., Zły język, w: Etyka międzyludzkiej komunikacji, red. J. Puzynina, Warszawa 1993, s. 33-38.

Kaczor M., Czynności mowy, które budują złe relacje międzyludzkie (na podstawie współczesnych sporów publicznych), w: Kontakty językowe w komunikowaniu, red. M. Steciąg, M. Adamczyk, M. Bieszczanik, Zielona Góra 2016, s. 339-352 (Zielonogórskie Seminaria Językoznawcze 2015).

Kaczor M., Jak uczestnicy dyskusji publicznych wypowiadają się o chciwości? Próba rekonstrukcji znaczenia, w: Media - Biznes - Kultura, red. B. Czechowska-Derkacz, D. Chomik, J. Wojsław, t. 2, Gdańsk 2018, s. 111-129.

Kaczor M., Krótko, ostro, do stuchu. Język współczesnych sporów publicznych (na przykładzie dyskusji o uchodźcach i migrantach w „Tygodniku Powszechnym”), w: Aksjologiczne aspekty komunikacji. Materiały z Forum Etyki Słowa, red. I. Benenowska, E. Laskowska, B. Morzyńska-Wrzosek, Bydgoszcz 2019, s. 81-98.

Kaczor M., „Lenistwo przerasta nasze siły”. Etyczno-moralny wymiar lenistwa (na przykładzie dyskusji publicznych), „Komunikacja i Konteksty” 1 (2018), s. 49-61.

Kaczor M., Struktura znaczenia leksemu pycha (na podstawie współczesnych debat publicznych). Szkic językowy, „Prace Naukowe Akademii im. Jana Długosza w Częstochowie. Filologia Polska. Językoznawstwo" 12 (2016), s. 107-120.

Kaczor M., Tabu a funkcja estetyczna języka, „Język Polski” 1 (2003), s. 46-49.

Kaczor M., Zazdrość jako problem etyczny (na przykładzie dyskusji publicznych), w: Etyka w komunikacji, red. G. Habrajska, Łódź 2018, s. 129-144 (Teorie i Praktyki Komunikacyjne).

Karwat M., O złośliwej dyskredytacji. Manipulowanie wizerunkiem przeciwnika, Warszawa 2006.

Klemensiewicz Z., Higiena językowego obcowania, „Język Polski” 45 (1965) z. 1, s. 1-8. Komputerowy słownik języka polskiego, Warszawa 2000.

McNair B., Seks, demokratyzacja pożądania i media, czyli kultura obnażania, Warszawa 2004.

Pawłowska R., Język rani i obraża, „Język-Szkoła-Religia” 6 (2011), s. 264-268.

Peisert M., Formy i funkcje agresji werbalnej. Próba typologii, Wrocław 2004. 
Praktyczny słownik współczesnej polszczyzny, red. H. Zgółkowa, t. I-L, Poznań 19942005.

Puzynina J., O zasadach współdziałania językowego, „Prace Filologiczne” 33 (1986), s. 61-66.

Puzynina J., Słowo-wartość-kultura, Lublin 1997.

Puzynina J., U podstaw etyki mowy, „Ethos” 2-3 (1988), s. 129-133.

Słownik języka polskiego, red. M. Szymczak, t. 1-3, Warszawa 1978-1981.

Słownik języka polskiego, red. W. Doroszewski, t. 1-11, Warszawa 1958-1969.

Słownik współczesnego języka polskiego, red. B. Dunaj, t. 1-2, Warszawa 1996.

Uniwersalny słownik języka polskiego, red. S. Dubisz, t. 1-6, Warszawa 2003. 